\title{
Hormonal control of adipose tissue lipolysis
}

\author{
By K. Siddle and C. N. Hales, Department of Medical Biochemistry, Welsh \\ National School of Medicine, Heath Park, Cardiff $\mathrm{CF}_{4}{ }_{4} \mathrm{XN}$
}

The activity of triglyceride lipase (triacylglycerol lipase; $E C$ 3.1.1.3) is regulated by a wide range of hormones, both lipolytic and antilipolytic, and this is one of the major points of regulation of triglyceride turnover in adipose tissue. The discovery of cyclic AMP and introduction of the 'second messenger' concept (Sutherland, Oye \& Butcher, 1965 ) led to the demonstration of the importance of cyclic AMP in mediating the action of hormones on lipolysis (Robison, Butcher \& Sutherland, 1971). We propose to discuss evidence that factors in addition to cyclic AMP are involved in mediating the effects of adrenaline and insulin on the enzymes controlling lipolysis in adipose tissue. Most of the experiments referred to have been performed on isolated fat cells (Rodbell, 1964 ), or fat pads, from the rat.

\section{Membrane receptors}

Both lipolytic and antilipolytic hormones are thought to interact first with the plasma membrane, and it has been proposed that they bind to hormone-specific receptor proteins. It is now clear that fat cells may possess more than one type of receptor for a given hormone. Binding studies have given little information about adrenergic receptors to date (Pairault \& Laudat, 1975). There is good evidence that activation of adenylate cyclase (EC 4.6.1.1) and stimulation of lipolysis at 'physiological' concentrations of catecholamines is mediated by $\beta$-adrenergic receptors (Robison et al. 1971) although the dose-response relationship for lipolysis is biphasic and at high concentrations the stimulation shows some different characteristics (Allen, Hillman \& Ashmore, 1969; Allen \& Beck, 1972; Desai, Li \& Angel, 1973). There is evidence that $\alpha$-adrenergic receptors mediate effects of adrenaline on $\mathrm{K}^{+}$efflux (Perry \& Hales, I970), phospholipid metabolism (Stein \& Hales, 1972) and glucose uptake (Luzio, Jones, Siddle \& Hales, 1974) in rat fat cells. Stimulation of lipolysis and elevation of cyclic AMP content may also be modulated by an $\alpha$-adrenergic inhibitory effect of catecholamines which is particularly prominent in man (Burns \& Langley, 1970; Robison, Langley \& Burns, 1972) and hamster (Hittleman \& Butcher, 1973; Hittleman, Wu \& Butcher, 1973), but also demonstrable in the rat (Perry \& Hales, 1970; Luzio et al. 1974). The significance of $\alpha$-adrenergic effects on adipose tissue at physiological catecholamine concentrations is uncertain, and the mechanism of these effects is unknown.

Studies of insulin binding to rat fat cells have produced conflicting results as to the number and affinity of insulin receptor sites (Cuatrecasas, 1971; Freychet, 
Roth \& Neville, 1971; Kono \& Barham, 1971; Gammeltoft \& Gliemann, 1973). Metabolic studies using high concentrations of insulin have shown a reversal of its effects on lipolysis (Hales, Chalmers, Perry \& Wade, 1968; Kono \& Barham, 1973), on cyclic AMP levels (Desai et al. 1973) and on adenylate cyclase (Hepp \& Renner, 1972; Illiano \& Cuatrecasas, 1972). It is difficult to imagine how a single class of high-affinity receptors (Cuatrecasas, 1971) could mediate responses over such a wide range of insulin concentrations. Other studies which described insulin receptors of comparatively lower affinity suggest that effects of insulin at physiological concentrations occur with only a small proportion of receptors occupied (Kono \& Barham, 197 I; Gammeltoft \& Gliemann, 1973). It is not certain whether the anomalous effects of insulin at high concentrations could result from further binding to the same type of receptor site, or from interaction with a separate class of receptors (Jerums \& Galton, 1974).

\section{Cyclic AMP concentration}

Adenylate cyclase and low- $K_{m}$ phosphodiesterase $\left(3^{\prime}: 5^{\prime}\right.$-cyclic-AMP phosphodiesterase; $E C$ 3.1.4.17), the enzymes which synthesize and hydrolyse cyclic AMP respectively, are both membrane-bound, and the cyclase is believed to be located in the plasma membrane. It is well established that adrenaline elevates cyclic AMP levels by stimulation of adenylate cyclase (Robison et al. 1971). Insulin has been shown to inhibit adenylate cyclase (Hepp \& Renner, 1972; Illiano \& Cuatrecasas, 1972), although some workers have not been able to reproduce this effect, and also to stimulate phosphodiesterase (Loten \& Sneyd, 1970; Schönhöfer, Skidmore \& Krishna, 1972; Manganiello \& Vaughan, 1973; Sakai, Thompson, Lavis \& Williams, 1974; Zinman \& Hollenberg, 1974). Little is known of the mechanism of interaction between hormone receptors and membrane enzymes, although it appears that GTP is involved in regulation of hormonal activation of adenylate cyclase (Rodbell, Lin, Salomon, Londos, Harwood, Martin, Rendell \& Berman, 1974; Siegel \& Cuatrecasas, 1974).

Increases in intracellular cyclic AMP after hormonal stimulation of isolated cells are only transient, although the proposed effects of the nucleotide such as stimulation of lipolysis are apparently sustained (Manganiello, Murad \& Vaughan, 1971) The fall in cyclic AMP content after an initial peak may be related to formation of a feedback regulator (Ho \& Sutherland, 1971; Ho, Russell \& Asakawa, 1975), to release of adenosine (Fain, Pointer \& Ward, 1972; Schwabe, Ebert \& Erbler, 1973) or to activation of phosphodiesterase by lipolytic agents (Pawlson, Lovell-Smith, Manganiello \& Vaughan, 1974; Zinman \& Hollenberg, 1974). These effects appear to be distinct from the cyclic-AMP-lowering and antilipolytic actions of insulin (Pawlson et al. 1974; Schwabe, Schönhöfer \& Ebert, 1974).

The relationship between cyclic AMP concentration and rate of lipolysis has been investigated particularly with regard to the action of insulin. In the presence of adrenaline, the lowering of peak cyclic AMP content by insulin is not sufficient to account for the amount of inhibition of lipolysis (Fig. I; and Siddle \& Hales, 1974a). Similar findings have been reported by Fain \& Rosenberg (1972), Kono \& 
Barham (1973) and Khoo, Steinberg, Thompson \& Mayer (1973). It appears that the total cyclic AMP content of the cell does not uniquely determine the rate of lipolysis, either when the effects of combinations of hormones are compared, or during the time course of action of a single hormone.

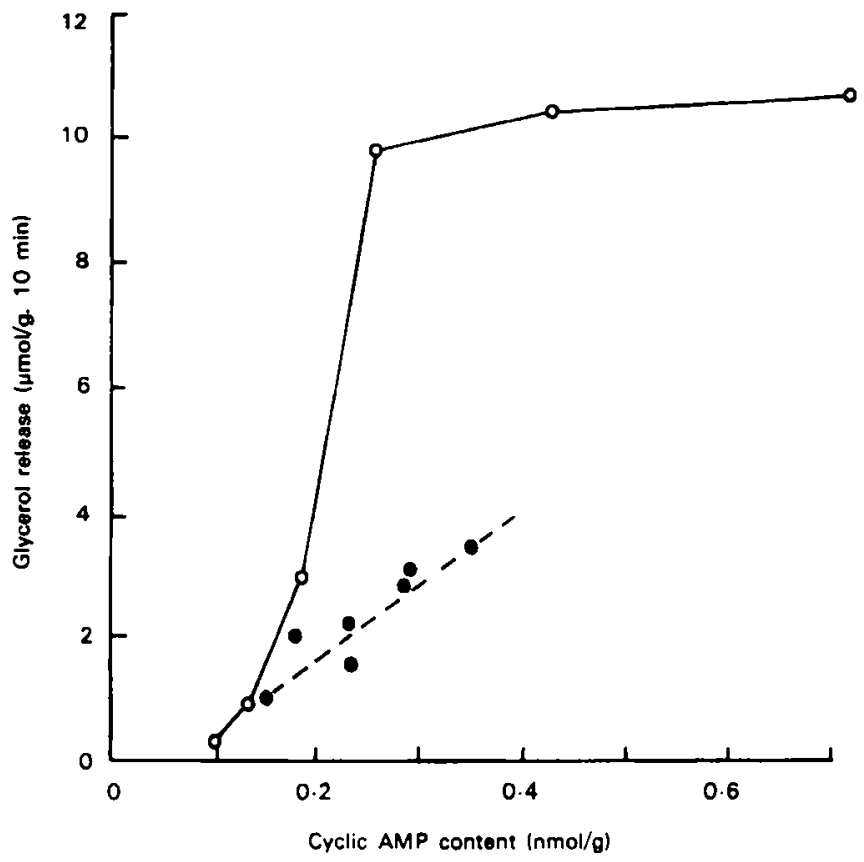

Fig. I. Relationship between cyclic AMP content and lipolysis in isolated rat fat cells; cells were incubated for $5 \mathrm{~min}$ and $15 \mathrm{~min}$ with various concentrations of adrenaline $(0.055-5.5 \mu \mathrm{M})$, with or without insulin ( $0.35 \mathrm{nM})$; the rate of lipolysis, measured by glycerol release between 5 and $15 \mathrm{~min}$, is plotted as a function of cyclic AMP content, measured at $5 \mathrm{~min}$. $O$, Adrenaline alone; 0 , adrenaline + insulin. From Siddle \& Hales (1974a).

\section{Protein kinase (EC 2.7.1.37)}

Intracellular effects of cyclic AMP are believed to involve activation of a protein kinase which modifies enzyme activity by phosphorylation (Krebs, 1972). The properties of adipose tissue protein kinase have been studied (Corbin, Soderling \& Park, 1973; Kissebah, Vydelingum, Tulloch, Hope-Gill \& Fraser, 1974; Corbin, Keely \& Park, 1975) and changes in activity in intact cells have been shown to parallel cyclic AMP levels under the influence of adrenaline and insulin (Soderling, Corbin \& Park, 1973). There is some evidence that factors other than cyclic AMP also influence protein kinase activity (Kissebah et al. 1974; Walaas, Walaas \& Gronnerod, I974; Larner, I975). There have been some difficulties in relating the properties of isolated protein kinase to apparent intracellular cyclic AMP concentrations, which have led to suggestions that cyclic AMP may be compartmentalized, with a substantial fraction sequestrated and metabolically ineffective (Kuo \& de Renzo, 1969; Park, Lewis \& Exton, 1972). This raises the possibility that hormones might act by modifying the distribution of cyclic AMP in addition to effects on total nucleotide content. However, it may be possible to 
explain the apparent anomalies in the interaction between cyclic AMP and protein kinase in intact cells without the need to postulate compartmentalization or participation of other factors (Beavo, Bechtel \& Krebs, I974; Swillens, van Cauter \& Dumont, 1974).

\section{Triglyceride lipase}

Triglyceride lipase has been studied in homogenates and partially purified preparations, but it has not been possible to obtain activation comparable with hormonal stimulation of lipolysis in intact cells. Lipase from rat adipose tissue is stimulated only $50-100 \%$ by addition of ATP, cyclic AMP and protein kinase (Rizack, 1964; Hales et al. 1968; Corbin, Reimann, Walsh \& Krebs, 1970; Huttunen \& Steinberg, 1971; Kissebah et al. 1974). Activation is paralleled by phosphorylation of lipase (Huttunen \& Steinberg, 1971; Kissebah et al. 1974) and activation is not possible when lipase is isolated from tissue previously stimulated with adrenaline (Hales et al. 1968; Huttunen \& Steinberg, 1971). Similar properties have been demonstrated with lipase preparations from human adipose tissue (Khoo, Aquino \& Steinberg, 1974) and somewhat greater lipase activation by cyclic AMP and protein kinase may be obtained using the enzyme from chicken adipose tissue (Khoo \& Steinberg, I974). It is possible that cell homogenization itself partially activates the lipase, or alters the balance between activating and deactivating enzymes, or disrupts the relationship between the lipase and triglyceride substrate. Alternatively, other factors may be involved in controlling lipase activity which are lost or diluted on homogenization.

\section{Role of ions in regulation of lipolysis}

$\mathrm{Ca}^{2+}$ ions have been shown to be important in addition to cyclic AMP in mediating the effects of a wide variety of hormones in many tissues (Rasmussen, Goodman \& Tenenhouse, I973). We have investigated the effect on lipolysis of agents which might affect intracellular $\mathrm{Ca}^{2+}$ content and distribution. Local anaesthetics inhibit adrenaline-stimulated lipolysis at concentrations which have little effect on fat-cell glucose uptake or ATP content (Fig. 2), while cyclic AMP content is further raised by the anaesthetic. The relative potencies of different anaesthetics parallel their effectiveness at inhibiting $\mathrm{Ca}^{2+}$ movement in various systems (Siddle \& Hales, $1974 b$ ). Preincubation of fat cell suspensions in medium containing the chelating agent ethylene glycol tetra-acetic acid (EGTA) and no $\mathrm{Ca}^{+2}$ also lowers adrenaline stimulation of lipolysis, but decreases glucose uptake and ATP content by a similar factor, suggesting that this effect may be non-specific and caused by disruption of fragile cells (Siddle \& Hales, unpublished results). However, apparently more specific effects of EGTA are seen if insulin is also present, when EGTA potentiates the antilipolytic effect and largely prevents the anomalous reverse effect at high insulin concentrations. Neither of these actions is explained by effects on adrenaline-elevated cyclic AMP content, which is further increased by EGTA, both with and without insulin (Siddle \& Hales, unpublished results). Inhibition of hormone-stimulated lipolysis by EGTA has also been shown in human adipose tissue (Efendic, Alm \& Löw, 1970). 


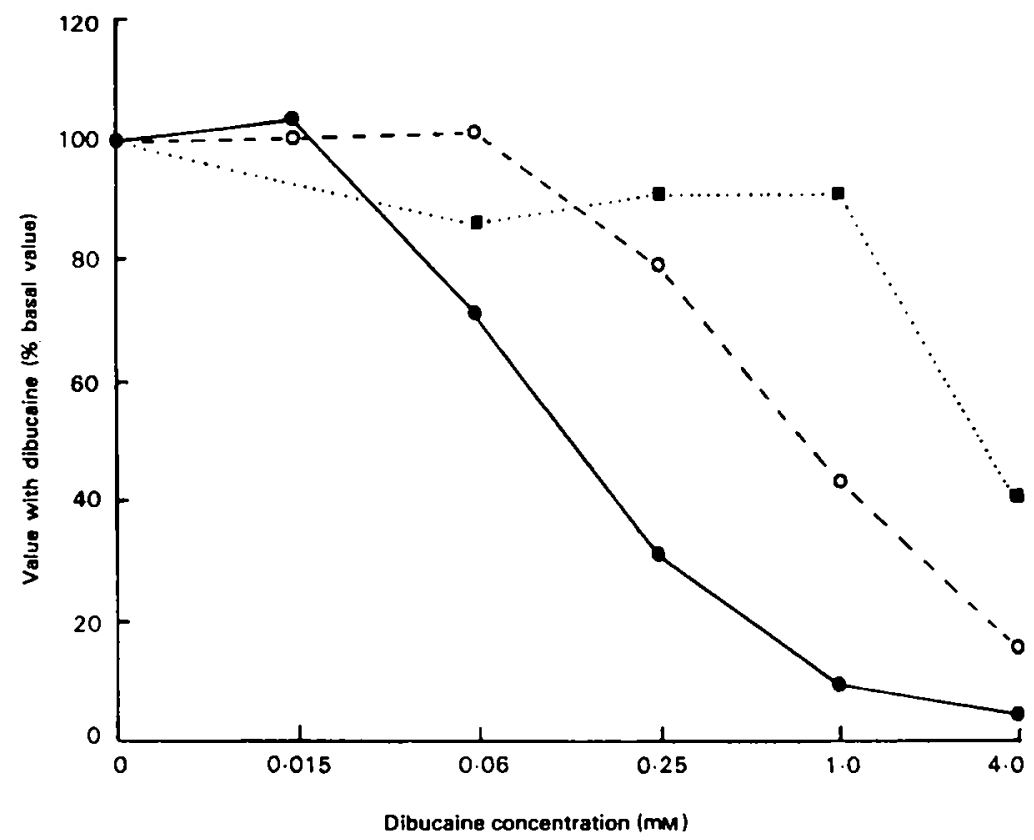

Fig. 2. Effect of dibucaine on lipolysis, glucose uptake and ATP content of rat fat cells. Cells were incubated with $5.5 \mu \mathrm{M}$-adrenaline and the local anaesthetic, dibucaine. ATP content (D) was measured at $30 \mathrm{~min}$ and glycerol release $(O)$ and glucose uptake $(O)$ after $60 \mathrm{~min}$. Results are expressed relative to the values without dibucaine (basal values), which were: glycerol release $80 \mu \mathrm{mol} / \mathrm{g}$ per $\mathrm{h}$; glucose uptake $75 \mu \mathrm{mol} / \mathrm{g}$ per $\mathrm{h} ;$ ATP content $210 \mathrm{nmol} / \mathrm{g}$ (from Siddle \& Hales, $1974 b$ ).

The actions of adrenaline and insulin on cell uptake and efflux of radioactive $\mathrm{Ca}^{2+}$ have been investigated in an attempt to assess the effect of hormones on free $\mathrm{Ca}^{2+}$ concentration in adipose tissue (Alm, Efendic \& Löw, 1970; Clausen, 1970; Clausen, Elbrink \& Martin, 1974; Werner, Hall \& Löw, 1974; Hope-Gill, Kissebah, Tulloch, Clarke, Vydelingum \& Fraser, 1975). Such studies have in some instances been interpreted to suggest that insulin elevates intracellular $\mathrm{Ca}^{2+}$ concentration and that this action mediates effects on intracellular enzymes (Clausen et al. 1974; Hope-Gill et al. 1975), although at present no direct measure of changes in intracellular free $\mathrm{Ca}^{2+}$ is available in fat cells.

A change in cytosol $\mathrm{Ca}^{2+}$ concentration could result from subcellular redistribution of the ion independent of exchange with the extracellular fluid. Isolated fat cells contain an ordered system of smooth endoplasmic reticulum, having a close relationship to plasma membrane, mitochondria and fat droplet (Hales, Luzio, Chandler \& Herman, 1974). The presence of $\mathrm{Ca}^{2+}$ associated with this endoplasmic reticulum has been demonstrated by pyroantimonate precipitation and X-ray microanalysis (Hales et al. 1974). This intracellular membrane system provides a possible structural basis for a store of $\mathrm{Ca}^{2+}$ which might be mobilized in response to hormonal stimulation. It has also been suggested that changes in mitochondrial $\mathrm{Ca}^{2+}$ may be responsible for changes in cytosol $\mathrm{Ca}^{2+}$ concentration (Rasmussen et al. 1973; Borle, 1974) and may be involved in the 
regulation of the mitochondrial enzyme pyruvate dehydrogenase ( $E C$ 1.2.4.1) by insulin (Martin, Denton, Pask \& Randle, 1972).

Further suggestive evidence for a role of $\mathrm{Ca}^{2+}$ has come from studies of the effects of glucocorticoids on adipose tissue. Adipose tissue from adrenalectomized animals shows an impaired lipolytic response to catecholamines (Reshef \& Shapiro, 1960) which is associated with a diminished sensitivity of the lipolytic enzymes to cyclic AMP rather than a decrease in cyclic AMP formation (Exton, Friedmann, Wong, Brineaux, Corbin \& Park, 1972). Also following adrenalectomy, fat cell $\mathrm{Ca}^{2+}$ uptake is diminished and the sensitivity of lipolysis to removal of extracellular $\mathrm{Ca}^{2+}$ is increased (Werner, Alm \& Löw, 1972), and it has been suggested that changes in responsiveness to cyclic AMP caused by glucocorticoid deficiency may result from changes in intracellular ion metabolism, particularly involving $\mathrm{Ca}^{2+}$ (Exton et al. 1972).

\section{Conclusions}

The relationship between changes in adipose cell cyclic AMP content and the effects of lipolytic hormones has been well documented but there remain many aspects of the control of lipolysis to be explained. Factors in addition to cyclic AMP almost certainly are involved in mediating the effects of both lipolytic and antilipolytic hormones on the activity of triglyceride lipase and on other metabolic processes in adipose tissue. At present these factors have not been identified, although there is circumstantial evidence that changes in intracellular $\mathrm{Ca}^{2+}$ may be important.

\section{REFERENCES}

Allen, D. O. \& Beck, R. R. (1972). Endocrinology 91, 504.

Allen, D. O., Hillman, C. C. \& Ashmore, J. (1969). Biochem. Pharmac. 18, 2233.

Alm, B., Efendic, S. \& Löw, H. (1970). Horm. metab. Res. 2, I 42.

Beavo, J. A., Bechtel, P. J. \& Krebs, E. G. (1974). Proc. natn. Acad. Sci. U.S.A. 71, 3580.

Borle, A. B. (1974). Ұ. Membrane Biol. I6, 221.

Burns, T. W. \& Langley, P. E. (1970). Y. Lab. clin. Med. 75, 983.

Clausen, T. (1970). Horm. metab. Res. Suppl. 2, 66.

Clausen, T., Elbrink, J. \& Martin, B. R. (1974). Acta endocr., Copenh. 77, Suppl. $191,137$.

Corbin, J. D., Keely, S. L. \& Park, C. R. (1975). F. biol. Chem. $250,218$.

Corbin, J. D., Reimann, E. M., Walsh, D. A. \& Krebs, E. G. (1970). f. biol. Chem. $245,4849$.

Corbin, J. D., Soderling, T. R. \& Park, C. R. (1973). F. biol. Chem. 248, 1813.

Cuatrecasas, P. (1971). Proc. natn. Acad. Sci. U.S.A. 68, 1264.

Desai, K. S., Li, K. C. \& Angel, A. (1973). 7. Lipid Res. 14, 647.

Efendic, S., Alm, B. \& Löw, H. (1970). Horm. metab. Res. 2, 287.

Exton, J. H., Friedmann, N., Wong, E. H. A., Brineaux, J. P., Corbin, J. D. \& Park, C. R. (1972). f. biol. Chem. 247, 3579 .

Fain, J. N., Pointer, R. H. \& Ward, W. F. (1972). F. biol. Chem. 247, 6866.

Fain, J. N. \& Rosenberg, L. (1972). Diabetes 21, Suppl. 2, $4^{1} 4$.

Freychet, P., Roth, J. \& Neville, D. M. (1971). Biochem. biophys. Res. Commun. 43, 400.

Gammeltoft, S. \& Gliemann, J. (1973). Biochim. biophys. Acta 320, 16.

Hales, C. N., Chalmers, T. M., Perry, M. C. \& Wade, D. R. (1968). In Protein and Polypeptide Hormones, part 2, p. 432 [M. Margoulies, editor]. Amsterdam: Excerpta Medica Foundation.

Hales, C. N., Luzio, J. P., Chandler, J. A. \& Herman, L. (1974). J. Cell Sci. I5, I.

Hepp, K. D. \& Renner, R. (1972). FEBS Lett. 20, I9 I.

Hittleman, K. J. \& Butcher, R. W. (1973). Biochim. biophys. Acta 316, 403.

Hittleman, K. J., Wu, C. F. \& Butcher, R. W. (1973). Biochim. biophys. Acta $304,188$.

Ho, R. J., Russell, T. \& Asakawa, T. (1975). Metabolism 24, 257. 
Ho, R. J. \& Sutherland, E. W. (1971). F. biol. Chem. 246, 6822.

Hope-Gill, H., Kissebah, A., Tulloch, B., Clarke, P., Vydelingum, N. \& Fraser, T. R. (1975). Horm. metab. Res. 7, 195.

Huttunen, J. K. \& Steinberg, D. (1971). Biochim. biophys. Acta 239, 4 Ir.

Illiano, G. \& Cuatrecasas, P. (1972). Science, N.Y. 175, 906.

Jerums, G. \& Galton, D. J. (1974). Horm. metab. Res. 6, 242.

Khoo, J. C., Aquino, A. A. \& Steinberg, D. (1974). f. clin. Invest. 53, 1124.

Khoo, J. C. \& Steinberg, D. (1974). Fै. Lipid Res. 15, 602.

Khoo, J. C., Steinberg, D., Thompson, B. \& Mayer, S. E. (1973). F. biol. Chem. 248, 3823.

Kissebah, A. H., Vydelingum, N., Tulloch, B. R., Hope-Gill, H. \& Fraser, T. R. (1974). Horm. metab. Res. 6, 247.

Kono, T. \& Barham, F. W. (1971). F. biol. Chem. 246, 6210.

Kono, T. \& Barham, F. W. (1973). F. biol. Chem. 248, 7417.

Krebs, E. G. (1972). Curr. Top. Cell Regul. 5, 99.

Kuo, J. F. \& de Renzo, E. C. (1969). F biol. Chem. 244, 2252.

Larner, J. (1975). Metabolism 24, 249.

Loten, E. G. \& Sneyd, J. G. T. (1970). Biochem. F. 120, 187.

Luzio, J. P., Jones, R. C., Siddle, K. \& Hales, C. N. (1974). Biochim. biophys. Acta 362, 29.

Manganiello, V. C., Murad, F. \& Vaughan, M. (1971). F. biol. Chem. 246, 2195.

Manganiello, V. \& Vaughan, M. (1973). F. biol. Chem. 248, 7164 .

Martin, B. R., Denton, R. M., Pask, H. T. \& Randle, P. J. (1972). Biochem. J. 129, 763.

Pairault, J. \& Laudat, M-H. (1975). FEBS Lett. 50, 6r.

Park, C. R., Lewis, S. B. \& Exton, J. H. (1972). Diabetes 21, Suppl. 2, 439.

Pawlson, L. G., Lovell-Smith, C. J., Manganiello, V. C. \& Vaughan, M. (1974). Proc. natn. Acad. Sci. U.S.A. 71, 1639 .

Perry, M. C. \& Hales, C. N. (1970). Biochem. F. 117, 615.

Rasmussen, H., Goodman, D. B. P. \& Tenenhouse, A. (1973). CRC crit. Rev. Biochem. I, 95.

Reshef, L. \& Shapiro, B. (1960). Metabolism 9, $55^{1 .}$

Rizack, M. A. (1964). F. biol. Chem. 239. 392.

Robison, G. A., Butcher, R. W. \& Sutherland, E. W. (1971). Cyclic AMP, ch. 6, p. 146; ch. 8, p. 286. New York: Academic Press.

Robison, G. A., Langley, P. E. \& Burns, T. W. (1972). Biochem. Pharmac. 21, 589.

Rodbell, M. (1964). \%. biol. Chem. 239, 375 .

Rodbell, M., Lin, M. C., Salomon, Y., Londos, C., Harwood, J. P., Martin, B. R., Rendell, M. \& Berman, M. (1974). Acta endocr., Coperh. 77, Suppl. 191, i I.

Sakai, T., Thompson, W. J., Lavis, V. R. \& Williams, R. H. (1974). Archs Biachem. Biophys. 162,331 .

Schönhöfer, P. S., Skidmore, I. F. \& Krishna, G. (1972). Horm. metab. Res. 4, 447.

Schwabe, U., Ebert, R. \& Erbler, M. C. (1973). Naunyn-Schmiedebergs Arch. exp. Path. Pharmak. 276, 133 .

Schwabe, U., Schönhöfer, P. S. \& Ebert, R. (1974). Eur. f. Biochem. 46, 537.

Siddle, K. \& Hales, C. N. (1974a). Biochem. I. 142. 97.

Siddle, K. \& Hales, C. N. (1974b). Biochem. F. 142, 345.

Siegel, M. J. \& Cuatrecasas, P. (1974). Mol. cell. Endocr. 1, 89.

Soderling, T. R., Corbin, J. D. \& Park, C. R. (1973). F. biol. Chem. 248, 1822.

Stein, J. \& Hales, C. N. (1972). Biochem. F. 128, 531 .

Sutherland, E. W., Oye, I. \& Butcher, R. W. (1965). Recent Prog. Horm. Res. $21,623$.

Swillens, S., van Cauter, E. \& Dumont, J. E. (1974). Biochim. biophys. Acta 364, 250.

Walaas, O., Walaas, E. \& Gronnerod, O. (1974). Acta endoct., Copenh. 77, Suppl. I91, 93.

Wermer, S., Alm, B. \& Löw, H. (1972). Horm. metab. Res. 4, 195.

Werner, S., Hall, K. \& Löw, H. (1974). Horm. metab. Res. 6, 319.

Zinman, B. \& Hollenberg, C. H. (1974). f. biol. Chem. 249, 2182. 